\title{
A NATURALIZAÇÃO PARA O EXERCÍCIO DO COMÉRCIO NA AMÉRICA DOS ÁUSTRAIS (II).
}

\section{(Continuação).}

YVONE DIAS AVELINO

do Departamento de História da Pontifícia Universidade Católica de São Paulo.

\section{CAPITULO III .}

\section{O TRÁFICO COLONIAL, EXCLUSIVO DE CASTELA (*).}

Se a extensa legislação espanhola, distribuída através de Cédulas Reais, pode, até certo ponto, oferecer um panorama das diretrizes políticas do Estado Nacional, nem sempre corresponde, todavia, ao concreto histórico. Discrepância entre a lei e a realidade: uma constante ou, ao menos, muito freqüente.

Leis houve - é correto dizê-lo - que foram maduramente elaboradas e posteriormente reeditadas e até mesmo ampliadas em diferentes momentos, num sinal certo de que a sua transgressão permanente reclamava e exigia da Corôa uma atenção reiterada e contínua. Normas jurídicas vigentes que não tinham a necessária eficácia. Em vista disso nem sempre alcançavam o seu objeto específico. Citaríamos, por exemplo, a legislação atinente à defesa ou proibição da passagem dos judeus para as Indias Ocidentais de Espanha, instaurada ao tempo dos Reis Católicos e constantemente renovada sob os Áustrias de Madrí.

Já na abertura do século XVI, logo em 1501, nas Instruções a Nicolau de Ovando, elevado à governança de Terra Firme, proibiam os Reis Católicos a passagem de estrangeiros e, ademais, ordenavam a expulsão daqueles que alí acaso se encontrassem, aos quais entretanto se permitia a posse dos bens que eventualmente tivessem. A

(*). - Surpreendeu-ros o artigo de Rozendo Sampaio Garcia - "Aspectos da economia e legislação espanholas", in Anais do Museu Paulista, T. XXIII, p. 173 e segs. S. Paulo, 1969 - que só em data posterior a êste Mestrado nos foi dado conhecer! 
Corôa nz̃o consentia sequer a permanência de feitor de negócios do Almirantado das Indias, de naturalidade estrangeira, pois, embora não determinasse de início a sua expulsão, pedia ao governador a sua identificação preliminar para posterior deliberação (51).

A Cédula Real de 1510, simples na forma mas complexa no conteúdo, assevera:
"Que no passem a la Indias ningunos estrangeros ni personas prohibidas so las penas de la pregmatica" (52).

A rea'eza, desde os primeiros tempos da colonização de seu patrimônio americano, instituiu um nacionalismo exclusivista para salvaguarda do trono e segurança do império ultramarino. Semelhante estanque descapitalizou o reino e a colônia, meio adequiado que a Corôa encontrou para preservar o trono e acautelar sua soberania política em terras e águas de seu patrimônio americano. A burguesia de Sevilha, com sua central no Guadalquivir, era a mais fiel representante do nacionalismo exclusivista espanhol, no qual a realeza figurava como principal empresário consorciado (53) .

A concessão privativa do direito ao comércio americano reservado aos castelhanos foi o traço inicial dêsse exclusivismo nacionalista, primeiro ensaio do Mercantilismo tradicional espanhol no ultramar.

Afigura-se-nos como legítima a tese de que a própria exclusão inicial dos aragoneses do trânsito das Indias Ocidentais de Espanha (54) tenha sido suscitada pelo interêsse da Corôa de impor limitação à poderosa nobreza de Aragão, sobremaneira ciosa de suas prerrogativas e tão duvidosa à conveniência e à estabilidade da nascente monarquia espanhola.

A extensão progressiva do direito de participação no comércio com as Indias Ocidentais aos naturales de estos reynos, consoante a fórmula nacionalista do tempo, foi consequiência antes do fortalecimento do poder real do que da evolução do próprio espírito nacionalista $(55)$.

(51). - Cf. - Encinas (Diego de), Cedulário Indiano. Ediciones Cultura Hispanica, pág. 441. Madrí, 1945.

(52). - Id $\mathrm{c} m$, pág. 440

(53). - Veja-se a citada tese de Manuel Nunes Dias, O Comércio Livre entre Havana e os portos de Espanha (1778-1789), $1^{\circ}$ vol., pág. 49.

(54). - Até 1504, conforme ensina Ramon Carande à página 317 de sua obra Carlos $V$ y sus. banqueros (1516-1556), editada em Madrí em 1943, não estava autorizada a passagem dos aragoneses às f́ndias Ocidentais de Espanha. Embora suscite dúvidas a época exata da permissão, sabe-se, todavia, que já em fins de 1511 eram extendidos os dircitos castelhanos aos aragoneses (Cf. Cédula Real de 9 de setembro de 1511).

(55). - Em fins do século XVI consideravam-se estrangeiros nas fndias de Espanha os não - naturais de Castela, Leão, Aragão, Valência, Catalunha, 
Assim se explica, seguramente, porque os empresários co'oniais portuguêses durante as seis décadas de sua incorporação aos destinos espanhóis através da chamada "Unificação Peninsular", embora vassalos dos soberanos de Madrí, jamais conseguiram o reconhecimento de direitos reservados aos naturais do reino espanhol, salvo em condições deveras excepcionais, pela naturalização adestrada por leis peculiares.

Podemos afirmar que a Espanha, no início de sua expansão colonial, ao tempo de Carlos V, admitiu apenas como nacionais aos naturalesi de estos reynos, como comprovam os documentos da época. Assim sendo, os demais eram considerados extranjeros.

Entretanto, sob essa rubrica, é essencial que se distingam duas situações particulares caracterizadas pela vassalagem ou não-vassalagem. Como estrangeiros-vassalos contaram-se, entre outros, genoveses, tudescos, flamengos e, mais tarde, os portuguêses. Estrangeiros não vassalos seriam, por exemplo, franceses e inglêses.

Dado o arraigado espírito de religiosidade da monarquia espanhola criava-se, ainda, uma situação muito particular em função do credo do estrangeiro, pois sòmente aos estrangeiros-cristãos se outorgavam certas franquias que jamais se reconheciam aos inimigos da fé-católica, judeus especialmente.

A política espanhola, quer no tempo dos Reis Católicos, quer sob os Âustrias de Madrí, com relação aos estrangeiros, variou muito. Semelhante inconstância da realeza achou-se sempre sob o infiuxo de fatôres diversos. Primeiramente em função das tendências personalistas de seus soberanos. Carlos $\mathrm{V}$, em virtude de sua idéia imperial e política financeira, coagido pelos compromissos sobremaneira onerosos que contraiu com banqueiros alienígenas, aproximou-se dos prestamistas estrangeiros aos quais fêz tais concessões que chegou mesmo a excitar os zelos dos espanhóis (56).

Alguns historiadores interpretaram essa atitude do primeiro dos Habsburgos do trono espanhol como fruto de sua política liberal.

Navarra, Maiorca e Minorca (Cf. Cédula Real de 13 de janeiro de 1596 em Coleccion de Leyes, Reales decretos y ordenes, t. V, págs. 172 e seg. Madrí, 1828). Veja-se ainda, no A.G.I. Reales Cédulas y Ordenes (1528 a 1784) Secretaria de Hacienda de Indias. Indiferente General. Leg. 2162.

(56). - Manifesto das Cortes espanholas em 1548:

"Que habiendo sido socorrido V.M. en Alemania y en Italia, ha sido causa de que vengan tanto numero de estranjeros que, no satisfechos con los negocios de V.M. de cambios y consignaciones, y no contentos con que no hay maeztragos, ni Obispados, ni Estados que no arrieden y disfruten, conpran todas las lanas, sedas, hierro y cueros y otras mercaderias y mantenimiento, que os lo que habia quedado a los naturales para poder tratar y vivir" (Carande R.), op. cit pág. 168). 
Estudos recentes tendem, porém, a demonstrar que o grande monarca agiu notadamente sob o imperativo das necessidades financeiras oriundas da problemática de seu imperialismo territorial, militarista e senhorial na Europa e na Africa do Norte (57).

A multidão de estrangeiros que passou à Espanha, com Carlos $\mathrm{V}$, foi aumentada pela quantidade apreciável de, católicos irlandeses introduzidos debaixo da proteção de Filipe II, seu filho e sucessor no trono, dado o clima de perseguições religiosas reinante em sua terra natal. Essa gente moça e ociosa, ávida de favores e mercês no reino e no ultramar, chegou a preocupar o Conselho de Estado em 1604. Finalmente em 1610 decide-se o seu afastamento da colônia e da metrópole mas, logo empós, no ano seguinte, a publicação de nôvo ato comprova o incumprimento da medida anterior (58).

Já Filipe II, embora governasse num sentido eminentemente espanhol, não poude se libertar do poderio absorvente do capitalismo fianceiro alienígena e adverso aos interêsses do trono. Premido igualmente pelas condições precárias das finanças do Estado, deixou-se entrelaçar pelos banqueiros estrangeiros que operavam dentro e fora do reino, acs quais fêz várias concessões grandemente repercussivas no ultramar e na metrópole. Eis porque implantou os asientos para o aprovisionamento de escravos negros para a América Espanhola, valioso setor da economia ibérica que nunca se libertou da tutela estrangeira (59).

Mas o que mais particulariza a administração espanhola é o contraste de sua política no tocante aos estrangeiros com relação à $\mathrm{Me}-$ trópole e às Indias de Castela. A Espanha, por fatôres vários, dependeu precìpuamente dos prestamistas estrangeiros que, desde os primeiros momentos da centralização monárquica peninsular, estiveram fortemente ligados à própria existência do Estado moderno. Entretan-

(57). - Cf. - Braudel (F.), Les Espagnols et l'Afrique du Nord de 1492 a 1577, in "Revue Africaine", 20 e 3." trimestres, págs. 31 e segs. Alger, 1928; Brandi (C.), Charles-Quint (1500-1558), págs. 285 e segs. Payot, Paris, 1951; Ricardi (Robert), Études hispano-africaines, págs. 143 e segs. Tetuan, s.d.

(58). - Cf. - Espejo (Cristobal), Las dificultades, economicas de España en el primer tercio del siglo XVII, págs. 25 e seg. Madrí, 1903.

(59). - O estudo dos asientos acha-se ainda por fazer, não obstante a riqueza da monografia do nosso sauduso professor Rozendo Sampaio Garcia, Contribuição ao estudo do aprovisionamento de escravos negros na América espanhola, 1580-1640. Separata n ${ }^{\circ}$ 16. dos "Anais do Museu Paulista". São Paulo, 1962). Vejam-se, por excmplo para semelhante abordagem, os Legajos do Archivo General de Indias de. Sevilla:

- Asiento de Negros (leg. 2766 a 2851);

- La Compañia de Portugal (Leg. 2778);

- La Compañia Real de Inglaterra (Legs. 2785 a 2786)

- Asiento de Portugal (Leg. 2848). 
to, enquanto a Corôa procurava atrair capitais alienígenas para o reino, criava conjunta e simultâneamente barreiras quase intransponíveis para a fixação dos empresários estrangeiros em seus domínios ultramarinos.

Para atender às suas necessidades comerciais (abastecimento de trigo, principalmente) a Espanha outorgou privilégios aos estrangeiros, sobretudo genoveses, que acorreram em grande número aos portos movimentados pelo giro mercantil - Sevilha, por excelência - onde se concentrava o intercâmbio com as praças de Flandres, França, Inglaterra, Itália, África do Norte e, por fim, as escápulas americanas.

Junto à Côrte eşoanhola não era menos notável a influência de poderosos banqueiros alienígenas, cuja colaboração se fazia indispensável para movimentar a complicada teia das finanças, que se devia estender por numerosas frentes por onde se espraiava o império espanhol, bem como para atender às permanentes necessidades internas do reino, especialmente dos encargos do trono.

Momentos houve, como em fins do século XVI, por ocasião do casamento de Filipe II, em que o Erário estava exausto e a fome e a peste reinavam em Madrí e noutras cidades, que a escassez do trigo era tal que muitas famílias passavam semanas inteiras sem ver o precioso alimento. A fome do pão era uma constante. Para superar momentâneamente o flagelo, acudiram os Fuggers com duzentos mil escudos para o rei e outros tantos para o arquiduque e a infanta, no momento em que a falta de numerário na Côrte era absoluta (60).

Já a passagem de estrangeiros para as Indias Ocidentais de Espanha era rigorosamente proibida por diferentes fatôres, dentre os quais avultaria o perigo que representava para o patrimônio colonial dos Áustrias espanhóis e para a unidade da fé católica.

Entretanto, desde os primeiros momentos da colonização esparhola na América verifica-se a presença de estrangeiros nos domínios da monarquia peninsular. Em 1503 assinala-se a presença de quinze empresários estrangeiros nos limites das concessões de Colombo, não obstante o impedimento categórico vasado nos seguintes termos:

"Yten, porque cumple a nuestro servicio, que en las dichas Yslas no aya estrangeros de nuestros reynos y senñorios, no dareys lugar que en las dichas Islas y tierra firme pueblen personas estrangeras de nuestros reynos, y si alguno vieredes agora, $y$ hallarades

(60).- - Perez Bustamente (C.), Felipe II, pág. 67: Madrí-Barcelona 1907; Galdácano (D. Gervasio de Artinano y de) Historia del comercio con las Indias durante el dominio de los Austrias, págs. $135 \mathrm{e} \cdot \mathrm{seg}$. Barcelona, 1917. 
que entre ellos han poblado, dareys orden como se vayan de alli: y si algunos bienes rayces tienen y los quisieren vender, proveerlo eys conforme a justicia. Y si alla huviere algun fator del dicho Almirante que sea estrangero avisarnos eys que persona es, y de que caidad, para que nos vos embiemos a mandar lo que se aya de hazer" (61).

Com o desenvolvimento da conquista, que revelou as riquezas minerais da América, produziu-se naturalmente o afluxo de estrangeiros que, à margem das leis, acudiam aos centros de exploração mineradora ou eram atraídos pelas vantagens do giro mercantil.

Um informativo documento do último quartel do século XVI dá-nos a idéia de como proliferavam os estrangeiros no importante centro minerador de Potosi, na época de Filipe II (62).

Não menos importante foi a afluência de mercadores portuguêses, judeus em sua maioria, atraídos pela prosperidade do Perú para onde afluiram em massa a tal ponto que chegaram a dominar inteiramente a principal praça comercial da América Espanhola no primeiro terço do século XVII (63). E, outrossim, tôda a história do Rio da Prata está polvilhada de nomes de estrangeiros que por alí transitaram ou se fixaram em conexão, principalmente, com o importante contrabando de éscravos negros, florescente no primeiro quartel do século XVII, quando os asientos de negros estavam em mãos de empresários coloniais portuguêses (64).

Como reagia a Corôa diante de uma situação de fato? Sucediam-se as Ordens Régias tendentes a resolver a inconveniência pelos caminhos legais: instauração de processo, condenação e expulsão do traficante estrangeiro.

Assim é que em face de representações, como a da Imperial Vila de Potosi, em 1579, sôbre a afluência de comerciantes estrangeiros naquelas paragens do patrimônio americano dos Austrias de Madrí, baixava Filipe II, em 1587, o seguinte decreto:

"El Rey. Conde del Villar pariente, mi Virey governador y Capitan general de las provincias del Peru, o a la persona a cuyo

(61). - A.G.I. Ordenes, Documentos y Expedientes del Asiento de Negros. Leg. 2786

(62). - Archivo General de Indias de Sevilha - Charcas, 35 (1579).

(63). - A.G.I., Asiento de Negros, leg. 2766; La Compañia de Portugal, leg. 2778; Asiento de Portugal, leg. 2848; Expedientes de Asientos para licencias de esclavos negros. Legs. 2829 e seg.

(64) - Ibidem. Vejam-se ainda os estudos de José Toríbio Medina, História del Tribunal del Santo Oficio de la Inquisición de Lima (1569-1820) 2 ts. Imprenta Guttenberg. Santiago, 1887 e de G. Scelle, La traite negrière aux Indes de Castille. Paris, 1906). 
cargo fuere el govierno dellas, yo he sido informado que es grande el numero de estrangeros que ay en essas provincias, y especialmente ne el cerro de Potossi, donde suben a la fama de su riqueza y que a esta causa ay mucha gente perdida y ociosa, de que resultan cada dia muertes y robos, y encarecerse excesivamente los bastimentos, y otros grandes inconvenientes: y porque como podreys considerar este es negocio de suma importancia, os mando que mireys mucho en el, y hagays para remedio de los dichos daños todas las diligencias que convengan, guardando las leyes que sobre ello hablan, y lo mismo embio a mandar a la mia audiencia Real de la provincia de los Charcas $\mathrm{y}$ al Corregidor de la dicha villa, avisareysme de lo que se hiziere. Fecha en Mostoles, a veinte y uno de Abril de mil y quinientos y ochenta y siete años. Yo El Rey. Referendada de Juan de Yvarra. Senalada del Consejo" (65).

Semelhante processo destinado a truncar o trânsito ilícito esbarrava com uma série de obstáculos de difícil remoção. Primeiramente $\checkmark$ poder econômico dos infratores, a cujo encontro vinha a venalidade das autoridades coloniais, permanentemente insatisfeitas e mal remuneradas pelo poder público (66). Depois os interêsses dos colonos, esquecidos geralmente pela estrábica política colonial espanhola e favorecidos pelo contrabando que não sòmente atendia às suas necessidades mais prementes como os aquinhoava no preço e na qualidade dos produtos.

Um outro aspecto, pouco conhecido, vem demonstrar que as dificuldades permanentes do Tesouro espanhol conspiravam para $o$ statu-quo, transformando em ducados a complacência para com os implicados na trama do trânsito ilícito (67).

Era a composición a transição de uma situação de fato para uma condição de direito. Valiam-se, pois, os comerciantes estrangeiros desta válvula de escape para fugir à sanção das leis.

(65). - Cf., Encinas (Diego de), op. cit., pág. 461.

(66). - "Los consejeros de Indias debian ser muy sensibles al poderoso efecto de las barras doradas,porque no obstante las diversas informaciones que llegabanhasta sus estrados, los contrabandistas se afianzaban en sus posiciones y los governadores eran condenados", (Torre Revello (José), Cronicas de Buenós Aires Colonial, pág. 6. Buenos Aires, 1943).

(67). - "Por el estado del erario fué politica adoptada la de tolerar, y aun permitir la residencia de extrangeros en Indias a fim de somertelos a composición y extraer de ellos pingues beneficios". (Cf. - Molinari (Diego Luis), La Trata de Negros, pág. 111. Buenos Aires, 1944). 


\section{CAPITULO IV.}

\section{BANQUEIROS-MERCADORES ESTRANGEIROS NO TRÁFICO.}

Se a Corôa espanhola procurou organizar o seu comércio com o ultramar, por intermédio de suas feitorias, companhias e outras mais entidades de direito público ou de direito privado, por sua vez, também os mercadores e prestamistas estrangeiros se dirigiram a Espanha em busca de possibilidades de desenvolvimento de suas poupanças.

Seria tarefa difícil e complexa tratar, nesta monografia de mestrado, em profundidade, de tão importante assunto econômico-social. Restringir-nos-emos, portanto, neste capítulo, a referir os esforços que representam conveniências de mercadores estrangeiros, na pretensão de conseguirem privilégios e regalias excepcionais dos monarcas espanhóis no trânsito americano, onde procuram estabelecer-se.

Informativos documentos que se acham guardados no Archivo General de Indias, em Sevilha, comprovam o que deixamos afirmado e assinalam os privilégios concedidos pelos Áustrias de Madrí a negociantes estrangeiros, notadamente mercadores portuguêses.

A Espanha, ultimada a centralização monárquica, particularizou-se no campo de sua política colonial por um exclusivismo comercial que se caracterizou pelo estabelecimento de portos privilegiados, pela instituição do regime das frotas e pela tentativa de nacionalização do sistema mercantil.

As falhas de semelhante regime foram enormes e influiram grandemente no desastre econômico-financeiro da monarquia espanhola. Realmente, dada a anemia capitalística do reino e a insegurança das regiỗes ultramarinas, os Áustrias de Madrí, todos êles, não estavam em condições satisfatórias para impor a nacionalização de seu comércio colonial. A Espanha não tinha estruturas adeqüadas para a montagem de um capitalismo. Não estava, portanto, aparelhada para a superação dos malefícios de seu mercantilismo. A nacionalização do tráfico afigurou-se ao trono como a salvaguarda da monarquia que, de um momento para outro, se viu senhora de um enorme império colonial que reclamava defesa em várias frentes.

Faltava-lhe, ademais, a que chamaríamos de vocação comercial, uma tradição econômica que conduzisse ao almejado êxito. Nenhum 
dos monarcas Habsburgos de Espanha tinha espírito capitalístico. Em contrapartida, todos os Áustrias de Madrí foram presos pela teimosia da política continental européia - constante peninsular com enormes e.maléficas repercussões para o processo de desenvolvimento econômico do reino e do ultramar.

À medida que a Espanha se esforçava para traçar diretrizes nacionalistas à sua política comercial, via fracassarem as energias altamente comprometidas pela falta de técnicos, pela precariedade dos capitais nacionais, pela ausência de estímulo de uma vocação mercantil que cedia lugar à experiência estrangeira .

E assim foi com efeito. Debalde tentou a Espanha numa experiência pioneira (68) que o comércio ultramarino se fizesse em barcos nacionais e com tripulação espanhỏla (69). Já em meado do século XVI, a Espanha tinha que admitir o concurso estrangeiro nesse importante setor da vida econômica, exausta pelas sangrias de suas aventuras imperialistas que comprometeriam, mais tarde, sèriamente, as possibilidades portuguêsas.

O terrível desastre naval de 1588 levou Filipe II a transigir no tocante à sua política exclusivișta. A Cédula Real de 11 de janeiro de 1590, ditada pela falta de marinheiros espanhóis qualificados para o despacho das frotas de Tierra Firme, admite, então, estrangeiros católicos, sobretudo italianos, com exclusão apenas de englêses ... (70).

Não menos nacionalistas eram as tendências comerciais da monarquia espanhola. Obrigada, entretanto, em diferentes momentos, a admitir a experiência estrangeira como ocorreu, por exemplo, no setor do comércio de escravos negros onde se exerceu inicialmente a hegemonia portuguêsa, a Espanha reagiu em alvoroços acionados pela aversão às pessoas e cousas estrangeiras - xenofobismo dos Áustrias de Madrí - contra a investida do Mercantilismo alienígena, deveras absorvente, que ameaçava o patrimônio americano (71).

(68). - "Mas tarde con las Actas de navegación se adotan (em Inglaterra) procedimientos puestos em boga por España y que, despues de 1588 no se logro llevar aqui a su ultima consecuencia" (Carande (R.), op. cit. pág. 96).

(69). - "La crise du navire est sans doute plus aigue, du fait de exigences nouvelles, mais malgré ces exigences et en raison sans doute de la crise, force est d'admettre des navires étrangers, em particulier les hourques" (Ct. 5103 - Sevilha - 21 de dezembro de 1554 - citado por Chaunu (H. et P.), Séville et l'Atlantique. Lib. Armand Colin, t. II, pág. 512 - nota. Paris, 1955.

(70). - Cf. - Braudel (F.), La Méditerranée et le Monde Méditerraneen à l'epoque de Philippe II, pág. 471. Paris, 1949.

(71). - "... l'atmosphère de xenophobie s'était échauffée depuis le temps de Coirea, tout recemment encore, une série de grands rapports et de polémiques 
Manuscritos espanhóis guardados no Archivo General de Indias de Sevilla evidenciam o surto dessa crise nacionalista, antilusitana por excelência, que se situa ao tempo de Filipe III, entre 1609 e 1614, quando eram incontestáveis os sintomas da depressão do comércio sevilhano e manifesta a superioridade do mercantilismo português no trânsito das Indias Ocidentais de Espanha (72), fielmente representado pelo Asiento de Portugal (73).

O fracasso do nacionalismo espanhol prende-se, sem dúvida, a várias razões - móveis profundos - mas nenhuma talvez tão forte $\mathrm{e}$ repercussiva como a crise econômica do reino esboçada sob Carlos V, agudizada no decurso do govêrno de Filipe II e prosseguida até os últimos Áustrias (74).

A desastrosa política financeira dos Habsburgos espanhóis levou a realeza à concessão a estrangeiros de privilégios e regalias que feriam frontalmente os interêsses nacionais no reino e no ultramar. Dêsses fatôres não participaram apenas os poderosos banqueiros estrangeiros cujos capitais eram investidos nas custosas emprêsas imperialistas (75) ou, ainda, na antecipação de fundos sôbre as rendas nacionais

avaient attaque la main-mise des étrangers sur les Indes de Castille: les marchands étrangers fuyaient l'Espagne avec leurs capitaux" (Chaunu (H. et P.), op. cit., t. I, pág. 215).

(72). - Cf. - Libelo contra os mercadores-banqueiros portuguêses que operavam no patrimônio americano dos Áustrias de Madrí. Trata-se de Rcpresentação do "prior y consules de la Universidad de los Cargadores de la ciudad de Sevilla", que viam nos negociantes-prestamistas portuguêses sérios concorrentes no tráfico indiano, especialmente no setor "del arrendamiento de la renta de las licencias de negros" (AGI., 1. G. 2795-1611).

(73). - AGI., Sección V, Legajo 2848. No comêço do século XVIII o "Asiento de Portugal" já se encontrava em fase de depressão devido à concorrência inglesa no tráfico de escravos africanos (Cf. AGI. - "Consultas y reales Ordenes sobre el Asiento de negros con la Compañia de Portugal y rescizión del Contrato" - 1695/1704. Legajo 2778).

Entre 1713 e 1753, pelo menos, o Asiento foi senhoreado pelos empresários inglêses que operavam no patrimônio colonial dos primeiros Borbons espanhóis. E o que Manoel Lello Belotto demonstrará proximamente em tese que vem elaborando sôbre a South-Sea Company, sociedade que induziu Filipe V - o primeiro Borbon de Madrí - a conferir aos Britânicos o Asiento para as fndias Ocidentais de Espanha.

(74). - Cf. - Carrion (J. L. Sureda) La Hacienda Castellana y los economistas del siglo XVII, págs. 75 e segs. Madri, 1943; Comeiro (Manuel), História de la Economia Politica en España, $1^{\circ}$ vol. págs. 39 e segs. Madrí, 1863; Hamilton (E. J.), The American Treasure and the Prices Revolution in Spain, 1501-1650, págs. 102 e segs. Harvard, 1934; War and prices in Spain 1651-1800, págs. 32 e segs. Cambridge, 1947.

(75). - A contribuição dos Fugger para a eleição de Carlos V a imperador abriu-lhes a porta para o comércio espanhol. Uma contribuiçăo de 100.000 duca- 
(76) arrendadas sistemàticamente a particulares alienígenas que, por vêzes, se faziam credores dos tributos de vários anos financeiros sucessivos.

À mingua de recursos procedentes do capitalismo estrangeiro enveredava a Corôa espanhola por caminhos embaraçosos que nem sempre consultavam os interêsses nacionais $\mathrm{e}$ as conveniências do próprio trono.

Veja-se, por exemplo, o que ocorria então no setor do comércio de escravos negros pelo Rio da Prata. Embora a administração espanhola tivesse a certeza de que por essa via americana transitava o grosso do contrabando que demandava a importante praça comercial do Perú no século XVII, embora as autoridades coloniais e o Conselho das Indias alertassem o poder real sôbre o perigo do tráfico ilícito por aquela região, preferia a Corôa comprometer-se em concessões temerárias que lhe aplainassem dificuldades financeiras momentâneas, ainda que as perdas futuras fôssem irreparáveis.

dos deu a Jacó Fuger o direito de acompanhar a frota das fndias por meio de seu próprio feitor. Era a primeira concessão dêste gênero. (Cf. - Hering (E.), Los Fucar en España, pág. 326. Fondo de Cultura Econômica. México, 1944).

(76). - Em $1^{\circ}$ de janeiro de 1525 os Fugger adquiriam por três anos os ingressos das Ordens de Santiago, Alcântara e Calatrava, estimadas em 135.000 ducados anuais. Durante os seis anos seguintes participaram com os Welser a quem também o imperador Carlos V devia fortes somas. Com exceção do período entre 1535 e 1557 os Fugger continuaram como arrendatários até o século XVII (Idem, págs. 329; Haring (C. H.), Comércio y navegación entre España y las Indias en la época de los Habsburgos, págs. 89 e seg. Trad. esp. Madrí, 1948; Ehrenberg (R.), Das Zeitalter der Fugger, t. I, págs. 102 e seg. Ieana, 1896. Há tradução francesa abrégée - Le Siècle des Fugger. Paris, 1955. 
CAPITULO V.

\section{NATUREZA JURÍDICA DO INSTITUTO DA NATURALIZAÇÃO.}

Organizadas as rotas do tráfico entre Espanha e suas Indias Ocidentais, através da central sevilhana, encontrou-se a finança internacional européia numa conjuntura realmente satisfatória para o impulso em iniciativas arrojadas. A Corôa, minguada em numerário, e necessitando cada vez mais de dinheiro para cobertura da sua política de salvaguarda do trono e de prestígio da monarquia na Europa, criou condições favoráveis para os banqueiros-mercadores estrangeiros.

A realeza, com os Reis Católicos, herdou uma economia em desordem, sobremodo abalada pelas repercussões do tumultuado processo militar da Reconquista peninsular. A tranquilidade devolvida à Espanha pela centralização do poder real restaurou o equilíbrio político e preparou o terreno para o incentivo ultramarino, que a ICorôa considerou a sua grande obra, fielmente representada pelo descobrimento da América.

Mas, na faixa política, a cautela e o bom-senso impunham a segurança do trono, que pode ter parecido excessiva, mas que aos reis espanhóis se afigurava a única solução viável para a afirmação da própria monarquia centralizada.

Todos os dados disponíveis confirmam que a Espanha era, então, um Estado moderno em desenvolvimento. Estava, porém, muito distanciada da pesição de um País de economia capitalista. A presença dos Áustrias de Madrí no Atlântico e no Pacífico americanos levou a Corôa a instituir a oligarquia econômica, expediente que se lhe afigurou adequiado às circunstâncias. Daí colocar-se a política como condição do próprio processo de desenvolvimento do seu mercantilismo.

A opção política que convinha ao trono era na realidade a da monarquia centralizada com um executivo forte e uma leal vassalagem. Insegurança e desconfiança levaram a realeza àquela preferência, embora isso naturalmente não a agradasse.

A Corôa vivia agarrada a valores do passado e, portanto, desligada da realidade do seu tempo. Assim se produziu a antinomia entre o Estado Nacional, politicamente centralizado, e o Capitalismo Moderno que buscava condições e espaço para crescer. 
Com o descobrimento da América e a subsequiente montagem do tráfico indiano, criou-se realmente uma conjuntura satisfatória com a evidência do prestígio adquirido pela monarquia. Mas o desfrute do comércio colonial ficou restrito a uma minoria aninhada em Sevilha, ro reino, e em Callao de Lima, na colônia. Ambas burguesias consorciadas - a sevilhana e a limenha - viviam isoladas da simpatia das demais fôrças econômicas nacionais. Tôda a orla portuária ficou fechada e retraída, embora não fosse insensível à riqueza ultramarina . Com isso a incipiente burguesia dos portos marítimos do reino ficou imobilizada.

Não bastou, todavia, à Corôa conluiar-se com Sevilha e Callao de Lima. O contrôle do tráfico enclaustrou a economia nacional espanhola precisamente numa época de crescente demanda de capitais. Daí a realeza encontrar-se na melancólica contingência de mancomunar-se com os prestamistas estrangeiros que acabariam por apoderar-se dos recursos fundamentais do reino e do império.

A tristonha opção da Corôa deve-se à falta de capital nativo e à ausência de espírito de emprêsa. Ambos fatôres condicionantes foram sobremaneira agravados com a idéia imperial dos reis espanhóis, permanentemente vivificada pela política continental européia.

A monarquia monopolística, com as suas supostas verdades absolutas, foi levada a contrair empréstimos junto à poupança privada estrangeira que, no seu entender, eram imprescindíveis.

A Corôa tinha a falsa impressão de que os veios argentíferos de Potosi e o azougue das minas de Huancavelica (77). eram mananciais inesgotáveis de riqueza. O tempo comprovou a impossibilidade de manter-se o rítmo das carregações coloniais da prata peruana (78). Ademais, os recursos do Real Erário sempre foram muito limitados, não obstante a amplitude da fronteira geográfica do reino e do império.

A monarquia nunca teve consciência de que se impunha um esfôrço de poupança traduzida por uma redução do consumo, notadamente numa época em que o mercador interno, em conseqüência da limitação do poder aquisitivo, era diminuto. De semelhante comportamento não poderia resultar nenhum aumento do produto interno bruto.

(77). - Cf. - Villena (Guillermo Lohamann), Las minas de Huancavelica en os siglos XVI y XVII. Sevilha, 1949.

(78). - Na segunda metade do século XVIII, a prata mexicana conquistou o lugar até então ocupado pela prata peiuana. É o que demonstraremos em nossa tese de doutoramento, Exportaçōes da prata mexicana pelo pôrto de Veracruz na época do "Comércio Livre" que vimos elaborando com documentação manuscrita guardada no Archivo General de Indias, em Sevilha. 
Tampouco nenhuma taxa de crescimento acusaria melhora da vida econồmica nacional espanhola, em virtude do grosso dos investimentos se realizar na faixa política.

O que figurava como meta prioritária era a segurança do trono e a salvaguarda do prestígio da monarquia na Europa. A realeza respirava uma atmosfera de otimismo excessivo, confiando na sua ação administrativa e vivendo a euforia do êxito da incorporação das Índias Ocidentais ao seu patrimônio. O objetivo fundamental era garantir a sua soberania no ultramar para ter condições de enfrentar o sistema do "equilíbrio" europeu.

Para isso os esquemas de segurança obrigavam a Corôa a uma reformulação de conceitos e de táticas. Expressão da vontade do trono, o govêrno tinha diante de sí, como um elemento prioritário a considerar, a preocupação de todo o dispositivo militar com o problema da defesa colonial e da preponderância política na Europa. Não cabe aqui o balanço de seus êxitos e de seus malogros, sobretudo das perdas a que sempre se submeteu à medida que aperfeiçoava, pela experiência adquirida, o esquema militar repressivo.

Era êste o principal problema da monarquia espanhola - constante dos Áustrias de Madrí - ao qual todos os mais deviam submeter-se. Isso exprime uma tendência de todo o sistema, imprimindo a marca de uma filosofia monárquica espanhola. A realeza sentia que precisava caminhar com extremas cautelas nas suas bases de sustentaçr̃o colonial. A verdade é que tôdas as aberturas estavam dependentes da defesa ultramarina e do prestígio do trono na Europa.

O comportamento da economia espanhola no decurso dos séculos XVI e XVII, em vista da primazia dada à fascinação da đorôa pelo setor político, nunca foi sátisfatório. Os contratempos ocorridos com o Real Erário sempre confirmaram, como indicadores, a depressão financeira da monarquia.

O poder de decisão era prerrogativa do trono - poder incontrastável característico da soberania da realeza. Todavia, o incremento da riqueza social nunca figurou com prioridade nos planos da Corôa.

O que importava era uma política que visava aproveitar-se ao máximo dos mercados que então representavam a riqueza colonial dos Áustrias de Madrí para aumentar, não o produto interno bruto, mas o acatamento no sistema continental europeu. Isso tornava a economia nacional espanhola cada vez mais sensível às flutuações dos preços no mercado internacional, conforme já o demonstrou E. J. Hamilton (79) .

(79). - The American Treasure and the Prices Revolution in Spain, 1501-1650. Harvard, 1934; War and prices in Spain, 1651-1800. Cambridge, 1947. 
De fato, no caso dos carregamentos de torna-viagem, verificaram-se sempre violentas flutuações nas cotações decorrentes da maior ou menor oferta, o que tornava a economia espanhola muito vulnerável à especulação do capitalismo alienígena. Porisso a monarquia e o capitalismo eram potestades antinímicas, que só um esfôrço inédito da realeza poderia conciliar.

A Espanha estava, com efeito, despreparada para se integrar num fato nôvo - o Capitalismo Moderno. A monarquia estava marcada por uma formação patriarcal e oligárquica. Era um País desprovido de capitais e carecido de mentalidade empresarial. Não estava, portanto, em condições para servir-se convenientemente da riqueza colonial.

Os reis espanhóis não optaram, portanto, pelos ideais do Capitalismo comercial. Mas encontraram-se na triste contingência de se entregarem ao jôgo da especulação estrangeira, sobremaneira usurária .

As crescentes dificuldades políticas da Corôa abriram, assim, brechas logo aproveitadas pelos financistas europeus. A conquista ultramarina e a organização do tráfico suscitaram problemas de dinheiro, momentâneamente resolvidos pelas operações bancárias junto aos prestamistas estrangeiros, que se não coadunavam com os interêsses do Estado Nacional espanhol.

O crédito constituía, então, dado o incremento do capitalismo comercial, uma atividade econômica sui generis, de fato, ao contrário de uma operação mercantil normal. Isso porque semelhante procedimento utilizava um capital nôvo que se não renova fàcilmente, enquanto se processa a rentabilidade do investimento.

A monarquia espanhola entenderia, certamente, o papel importante que deveria desempenhar na estratégia do desenvolvimento econômico a utilização do instituto do crédito, numa época em que o Real Erário, minguado em capitais vivos, necessitava, cada vez mais, de dinheiro que se traduzia em grossas sangrias do organismo nacional.

Com isso a Corôa abriu perspectivas ao desenvolvimento do tráfico colonial americano, favorecendo o setor privado detentor de numerário.

Essa a realidade capitalística do trono. O Estado Nacional carecia de dinheiro. Os seus interêsses levaram-no, então, a instituir e a vulgarizar certos títulos de crédito e determinadas mercês ou privilégios, inclusive incentivos fiscais com propósitos de fomento da riqueza colonial (80).

(80). - Semelhante comportamento da Corôa encontra-se, contemporâneo, em Portugal, no tempo dos Avís. Veja-se o estudo de J. Denucé, Priviléges commerciaux accordés par les rois de Portugal aux Flamands et aux Allemands $(X V$ et $X V I)$, in "Archivo Histórico Portuguez", t. VII, págs. 310 e segs. Lisboa, 1909. 
Dêsse conluio, singular arranjo entre o poder público e o setor privado, um precisando de dinheiro para a sua política, outro convivendo e sustentando seus empreendimentos financeiros com o engenho da especulação usurária, cosmopolizou-se o Instituto da Naturalização.

Trata-se de um instrumento legal para o exercício do comércio de estrangeiros na América Espanhola no tempo dos Áustrias. De Carlos I a Carlos II, no decurso de dois séculos (81), tal expediente foi uma constante.

Através da Naturalização, banqueiros-comerciantes estrangeiros operaram no tráfico indiano. Só por mercê régia é que o comerciante alienígena podia tratar no reino ou no ultramar. Sem a concessão da Corôa nenhuma transação econômica realizada por estrangeiros, dentro das fronteiras geográficas do patrimônio da realeza, era considerada lícita, figurando, assim, no rol do contrabando. A Recopilación das Indias Ocidentais de Castela vedava, realmente, o comércio exercido por estrangeiros na América Espanhola sem o devido consentimento da Corôa, que se representava como retribuição do poder público a determinados credores do trono interessados (82).

E assim era com efeito. Na partida dos galeões e das frotas, cabia ao presidente e aos juízes da Casa de La Contratación proceder às averiguações que se faziam necessárias a fim de se impedir o embarque de comerciantes estrangeiros com destino à América dos Ãustrias (83) . E' evidente que os "testas de ferro" agiriam, embora não às soltas, em conivência com certos funcionários devassos ou fraudulentos. Mas, é claro, estavam sempre sujeitos a severas penas de conformidade com a legislação vigente.

O Instituto da Naturalização de estrangeiros para o exercício do comércio na América Espanhola era representado, em sua forma, por uma Carta - Carta de Naturaleza. Não era nenhum contrato de fretamento de qualquer embarcação, para uma ou mais viagens às Indias Ocidentais de Castela. A Naturalização era uma concessão. O rei figurava na relação jurídica não apenas como simples parte mas, sim, como concessionário. Tratava-se, portanto, de uma outorga da realeza a determinados banqueiros-mercadores, seus prestamistas e credores.

(81). - Carlos I (1516-1555), Felipe II (1556-1598), Felipe III (1598-1621), Felipe IV (1621-1665) e Carlos II (1665-1700).

(82). - "Que nenhum estrangeiro possa tratar na Indias ou no Reino, sem estar habilitado con naturaleza, y licencia nuestra" (O grifo é nosso). Veja-se a Recopilación de leyes de los reynos de la Indias, t. III, Libro VIrII, Titulo XXVII, págs. 326 e segs. Imprensa do Real y Supremo Consejo de las Indias. Madri, 1791.

(83). - Idem, Ley ij, pág. 326. 
Era uma cessão, não do exclusivismo do tráfico, mediante certas condições, mas de passaporte para as Indias de Espanha com finalidade mercantil.

O consentimento do soberano, concretizado ou formalizado na Carta de Naturaleza era uma mercê, um favor prestado pelo Estado Nacional representado pela vontade do trono. E o banqueiro-prestamista era o aquinhoado. O rei era, afinal, fonte permanente de Direito.

O fundamento do Instituto era a Carta, espécie de título de crédito. A naturalização não indicava o ato pelo qual o estrangeiro, renunciando sua nacionalidade de origem, adotava a espanhola. Nada disso acontecia, visto tratar-se de uma figura jurídica que se insere no âmbito do Direito Comercial. E' exato que o Instrumento Carta pertence ao Direito Público, pois é uma concessão régia a Naturaleza. Mas o exercício do comércio é do Direito Privado - Direito Mercantil.

O Instituto é realmente uma autorização do Estado a determinados financistas-mercadores para a prática de atos de comércio na América Espanhola. O prestamista beneficiado pela mercê da Corôa ficaria, assim, devidamente registrado nos Livros da Casa de la Contratación, com direito assegurado pela realeza para embarcar, fretar e operar no tráfico indiano $(84)$.

A Naturalização não equiparava o estrangeiro ao nacional esparhol - peninsular ou crioulo. O privilegiado tinha apenas licença para praticar atos de comércio. Nada mais que isso. Ele, banqueiro-mercador estrangeiro, não se investia nos mesmos direitos assegurados ao nacional. Há, com efeito, certos direitos políticos e, mesmo, determinadas funções que são privativos do cidadão nato, dos quais não pode participar o naturalizado.

Os princípios fundamentais para a Naturalização eram fixados na própria Carta que a Corôa concedia. E, por êles, a mercê régia adquiria-se de modo expresso, porquanto resultava de pedido do próprio estrangeiro interessado na negociação, nos têrmos da lei que a estabelecia, e concedida pela realeza mediante provisão.

(84). - Vejam-se as Cartas de Naturaleza concedidas pela Corôa aos banqueiros-mercadores portuguêses: Duarte Fernandes da Costa, Antônio Nunes G amacho, Francisco Jorge, Simão Rodrigues Bruno, Simão Ribeiro, Francisco Lobo da Cunha, Nicolau da Veiga, Francisco Lopes de Sevilla, Henrique de Andrada, Marcos Góes de Moraes, Afonso e Gaspàr Rodrigues Passarinho. Essas Carta de Naturalização acham-se, manuscritas e ineditas, no Archivo General de Indias, em Sevilha (Cf. Contratación 179; Contadoria 1391 ; Charcas 35 e Indiferente Ge-1 neral 2795). 
Com isso os Áustrias descortinaram perspectivas inteiramente novas ao processo de desenvolvimento do tráfico colonial, pelo setor privado estrangeiro. Foi, cremos, uma solução política natural para o trono. A realeza precisava do crédito estrangeiro que então figurava no programa do govêrno como base de sustentação política.

As dificuldades financeiras da Corôa abriram, assim, profundas brechas no concretado tráfico colonial, logo aproveitadas pelos calcu'istas banqueiros-mercadores estrangeiros que operavam nas rotas do Atlântico e do Pacífico americanos com enorme margem de lucro e sempre ao abrigo da monarquia espanhola.

Apuramos, afinal, como ensaio de exemplificação concreta, a Naturalização de prestamistas portuguêses, certamente judeus ou cristãos-novos. E' o que veremos a seguir. 


\section{CAPITULO VI.}

\section{A NATURALIZAÇÃO DE PORTUGUESES, FONTE DE FINANCIAMENTO.}

Para equiparar-se aos naturais do reino através da Carta de $\mathrm{Na}$ turaleza, caminho único para adquirir o direito de passar às Indias Ocidentais, alí residir e praticar o comércio (85), devia o estrangeiro preencher os requisitos seguintes de conformidade com o fundamento legal: residência na Espanha há mais de vinte anos (86), ser casado com mulher espanhola e possuir bens de raiz. Não obstante, a discrepância entre a lei e a realidade foi uma constante... !

A Carta de Naturaleza, de sanção real, era submetida prèviamente à apreciação do Conselho das Indias .

Se nem sempre as petições de naturalização mereciam o beneplácito da Corôa (87), são sobremaneira informantes os documentos coligidos acêrca da naturalização de comerciantes portuguêses, não sòmente por se tratar de assunto muito pouco conhecido, senão inteiramente inexplorado, como pela oportunidade das conclusões a que nos levam sôbre a política econômica dos primeiros Áustrias de Madrí, que singulariza o sistema colonial espanhol.

Em princípio, na documentação reunida e analisada, apenas um caso se apresenta com os requisitos essenciais para a obtenção da naturalização nos têrmos precípuos da lei. Trata-se do processo de Francisco Lopes de Sevilha que a 8 de junho de 1626 alcançava o favor pleiteado invocando as seguintes credenciais:

(85). - ... passar, estar, residir, rescatar, tratar y contratar nos têrmos da Iegislação vigente.

(86). - Alterado mais tarde para dez anos.

(87). - Candidatando-se à posse do asiento de negros em 1622 pretendia - empresário colonial Manuel Rodrigues Lamego, entre outras cousas:

“... que S. M. ha de ser servido conceder al dicho Manoel Rodrigues Lamego y a sua muger y a dos niños que tiene cedula de naturaleza destos Reynos de Castilla pues son portugueses y que desde oy adelante gocen de todas las esempciones, libertades $\mathrm{y}$ prerrogativas de que goçan los naturales dellos y assi mismo que pueda tratar y contratar en Yndias desde Sevilla dande determina mudar "su casa" (AGI. - IG., Leg. 2796. Ano de 1622).

O despacho lacônico - No ha lugar - mostra até que ponto não estava a Corôa disposta, no momento, a ferir o direito dos naturais. 

a). - mais de vinte anos de vencidad em Sevilha;
b). - ser casado com mulher natural dos reinos de Castela $\mathrm{e}$
c). - ter bens de raiz de valor superior a cinco mil ducados (88).

$\mathrm{Na}$ maioria dos casos os candidatos mercadores à Carta de Naturalizaçz̃o requerem simplesmente a dispensa de um dos requisitos essenciais. Assim é o caso do empresário Francisco Jorge (89) que viu sua pretensão deferida a 23 de novembro de 1617. Ainda que fôsse residente em Sevilha há mais de vinte anos, casado com mu'her natural dos reinos de Castela e possuisse propriedades, não apresentava bens de raiz (90).

Maior liberalidade se evidencia na concessão da naturalização a Nicolau da Veiga e seus filhos Rodrigo e Manuel (91), beneficiados em 8 de março de 1631, porquanto da Cédula Real que lhes outorgou o direito de se equipararem aos naturais dos reinos de Castela consta apenas alguns aros de residência no reino. Dispensavam-se qualesquier requisitos que os falten, segundo a linguagem protocolar encontradiça em vários documentos manuscritos desta série.

Quase idêntico é o caso de Simão Ribeiro (92) aquinhoado na mesma época (16 de maio de 1631) com título semelhante, porquanto da justificação da concessão constava apenas que residia no reino há alguns anos e tinha a intenção de aí permanecer (93).

Dada a circunstância habitual de se fundarem as concessões reais em obteção de vantagens de múltipla ordem, é de se supor que êstes comerciantes beneficiários houvessem concorrido de qualquer forma para alcançar a graça do trono. Todavia, o silêncio dos documentos que analisamos não permite uma conclusão real e objetiva como a que reçuma dos manuscritos que passaremos a analisar.

A situação do Tesouro espanhol sempre à míngua de recursos, principalmente depois da grave crise que se projetou nos primeiros tempos do govêrno de Filipe II, entre 1575 e 1578, influiu decisivamente nas diretrizes dos monarcas espanhóis, com relação à política com os estrangeiros, mormente portuguêses, no período da unificação peninsular (1580-1640).

(88). - AGI. - Contratación 179. Carta de "Naturalez" de Francisco Lopes de Sevilha.

(89). - Idem, Contratación 179. Carta de "Naturaleza" de Francisco Jorge.

(90). - Ibid!m.

(91). - AGI. - Contratación 179. Carta de Naturaleza" de Nicolau da Veiga.

(92). - Idem, Contratación 179. Carta de "Naturaleza" de Simão Ribeiro.

(93). - Ibidem. 
A atitude peculiar dos Habsburgos espanhóis de recorrerem à bôlsa dos banqueiros prestamistas estrangeiros para atenderem às suas múltiplas necessidades internas e externas (94), obrigava-os a larga liberalidade, pois já não bastava o mero atrativo dos juros para drenar capitais que se retraiam em face da pouca ou nenhuma segurança das finanças do Estado.

Grande interêsse tinha a Corôa espanhola em obter a participação de empresários coloniais portuguêses, no complexo mecanismo de transferência de fundos para o exterior, dadas as ramificações dos negociantes lusitanos pelos principais empórios por onde se expandia o capitalismo comercial na Europa continental e no ultramar (95).

$\mathrm{O}$ instrumento contratual era $\mathrm{o}$ asiento - relação jurídica entre a Corôa e os financistas - onde se fixavam geralmente as bases do negócio como o quantum, os juros, o local e a forma de pagamento, o destino da soma emprestada, bem como outras condições ocasionais como as que estipulavam vantagens excepcionais. Dentre estas não foram raras, principalmente ao tempo de Filipe IV, as concessões de Cartas de Naturaleza como prêmio suplementar aos financiadores pessoalmente mas a empresários por êles indicados.

Tais eram os benefícios da naturalização que abria $a$ priori as portas do comércio americano para os capitalistas estrangeiros. Afigura-se-nos, é de admitir-se, fôsse êste privilégio um fator atrativo para a arriscada trama dada à precária condição de solvabilidade do Tesouro espanhol.

Outra encrme vantagem que alcançavam os mercadores-banqueiros portuguêses através da naturalização era a imunidade à sangria de seus bens, processada comumente durante a unificação peninsular por meio de inúmeros tributos com que os comerciantes lusitanos, lisboetas e portuenses por execelência, cram obrigados a concorrer para minorar os apuros da Corôa espanhola agravados pela ocupação do Brasil pelos holandeses. Veja-se, por exemplo, a forte contribuição das cidades portuguêsas, Lisboa principalmente, para auxílio em 1631

(94) . - . "Chargé de réseoudre le difficile problème des provisions de Flandres, le Conseil des Finances fit incontestablement des progrès dans l'art d'utiliser les hommes d'affaires pour le service de l'Etat. Après avoir accepté des paiements en pays étranger ou hostile comme la France, ou dans des territoire trop éloignés des Pays-Bas, comme à Francfort, en Savoie ou en Italie, solutions boiteuses qui encourageaient la spéculation..." Lapeyre (Henri), Simon Ruis et les asientos de Philippe II, pág. 103. Libr. A. Colin. Paris, 1953).

(95). - Cf. - Dias (Manuel Nunes), O Capitalismo Monárquico Português (1415-1549) Contribuição para o estudo das origens do capitalismo moderno, vol. II, págs. 321 e segs.; Prada (V. Vazquez de), Lettres marchandes d'Anvers, t. I, págs. 201 e segs. Coleção "Affaires et Gens d'Affaires". Paris, s. d. 
destinado à causa da libertação de Pernambuco (96), a que concorreram alguns dos empresários coloniais, credores do trono, fielmente representados por Afonso Rodrigues e Gaspar Rodrigues Passarinho, Simão Rodrigues Bueno e Jorge da Paz da Silveira (97).

Por uma cláusula da Carta de Naturaleza concedida a 28 de janciro de 1641 aos irmãos Rodrigues Passarinho (Afonso e Gaspar), atingidos por uma contribuição de duzentos mil ducados no empréstimo de 1631 para a causa nacional e patriótica da libertação de Pernambuco, estabelece-se a futura isenção dos naturalizados, a partir daquela data, nestes termos deveras categóricos:

\begin{abstract}
“... para que entodas cosas y casos que se ofrecieren seais avidos y tenidos por naturales de ellos (reynos de la corona de Castilla) sin que en ninguna manera podais ser havidos ni reputados por portugueses, llamados ni compreendidos en ningunas juntas ni contribuciones que se ovieren de hacer por los naturales del dicho reyno de Portugal ni en particular ni en general ni sobre ello se os pueda convenir en manera aguna ..." (98).
\end{abstract}

Idêntica concessão fôra outorgada poucos dias antes ( 6 de janeiro de 1641), logo no ano subseqüente à Restauração portuguêsa, a Enrique de Andrade e seus filhos, vecinos de Sevilha, partícipe de um asiento de 383.000 ducados, correspondentes à contribuição da praça de Sevilha no famoso empréstimo de dois milhões de ducados lançado no anterior pela administração espanhola (99).

O caminho para a isenção à avidez do fisco não era uma novidade: em Portugal, comerciantes cristãos-velhos, tão logo alcançavam fortuna, tratavam de nobilitar-se. O mesmo faziam os cristãos-novos apesar dos entraves que lhes eram opostos às suas pretensões nobilitantes $(100)$.

O processo devia ser o mesmo na Espanha. Assim, pelo menos, o confirma a informação de Sancho de Sopranis que, em seu estudo sôbre Cadiz no século XVI (101), afirma que os mercadores-banquei-

(96). - A. N. T. T. - Corpo Cronológico, Maço 118, Doc. 105.

(97). - Ibidem.

(98). - AGI - Contratación 179. Carta de "Naturaleza" de Afonso e Gaspar Rodrigues Passarinho. Andrade.

(99). - Idem, Contratación 179. Carta de "Naturaeza" de Henrique de

(100). - A. N. T. T. - Corpo Cronológico, Maço 118, Doc. 105.

(101). - Sopranis (Hipólito Sancho de), Perfil demográfico de Cadiz en el siglo XVI, em "Estudios de Historia Social de España", t. II, pág. 567. Madri, 1952. 
ros que acorreram àquele pôrto dos Austrias de Madrí, notadamente genoveses, flamengos, portuguêses, florentinos e franceses,

"acompañandoles la suerte, se encumbraran con rapidez a las primeras magistraturas, entrando a formar parte de la nobleza local" (102).

Todavia, a concessão mais generalizada de naturalização em função de compromissos por via de asientos era para o exercício do comércio com as Indias Ocidentais de Espanha através da fórmula preceitual corrente em todos os documentos:

“... carta de naturaleza de estes mis reinos de Castilla para que pudieseis tratar y contratar desde ellos a las dichas Indias y desde ellas a estos mis reinos como hacen los naturales de ellos aungue vos no lo seais" (103).

Confirmando e ampliando êste direito confere ainda ao comerciante naturalizado:

“... gracias, mercedes, franquicias, libertades, preeminencias, prerrogativas e immunidades de que gozan y pueden gozar en las dichas Indias los que son naturales de estos mis Reinos de Castilla para el dicho efecto de tratar y contratar en ellas" (104).

Várias são as concessões de Carta de Naturaleza oferecidas ao próprio interessado e parentes ou a pessoas por êle indicadas para beneficiários da graça real.

Dos casos examinados o mais atraente é, sem dúvida, o de Antônio Nunes Gramacho que não apenas concorre num asiento com a grossa soma de 14.000 ducados de prata doble para atender às necessidades do serviço real (105). Acresce notar que à altura da concessão já levava mais de vinte anos de residência em Cartagena, na América, onde devia ter acumulado fortuna a julgar pela

"mucha cantidad de bienes raices en la dicha ciudad de Cartagena",

onde com suas armas, cavalos e criados acudira em defesa da cidade, em companhia de seu filho Jorge Fernandes Gramacho (atingido também pelos benefícios da naturalização),

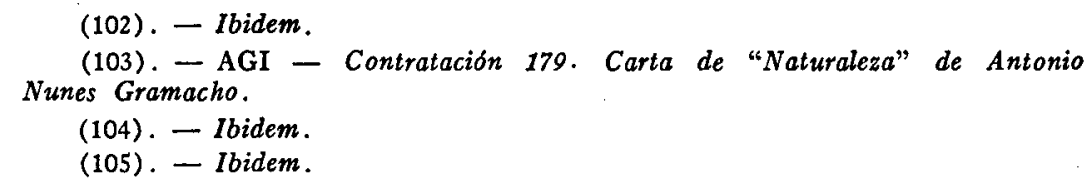


"con mucho amor y fidelidad procurando el aumento de mi real hacienda y el bien publico de aquella provinzia.." (106).
\end{abstract}

Em benefício de seu próprio filho Duarte Fernandes da Costa (107) acode, em 1629, Duarte Fernandes que em companhia de Manuel da Paz e Simão Scares concorrera com a grossa soma de 655.000 escudos num asiento para a provisão de necessidades do serviço da Corôa, através do qual cada um đos três financistas adquirira o direito de indicar um beneficiário de Carta de Naturaleza (108).

A mais remota Carta de Naturalização, em que prevalece o princípio de indicação de terceiros em função de compromisso assumido pela realeza com assentista, encontramo-la em 1630 quando o empresário colonial Simão Rodrigues Bueno (109) adquire o direito de equiparação aos naturais de Castela por indicação do mesmo financista-mercador Duarte Fernandes, que contribuira naquele ano com 225.036 escudos para atender aos apuros do trono (110).

Dois anos depois o poderoso banqueiro Jorge Paz da Silveira obtinha o privilégio de indicar dois beneficiários da naturalização para duas pessoas que indicasse quando concorria com apenas 50.000 escudos para Flandres. Um dos favorecidos foi o comerciante Marcos Góis de Morais que se dedicava ao tráfico de escravos negros africanos e que operava nas rotas do Atlântico americano (111).

Em 1634 encontramos novamente Duarte Fernandes concertando com a monarquia espanhola um empréstimo de 300.000 . escudos para prover necessidades dos Áustrias de Madrí nas praças de Flandres e Alemanha colhendo, entre outros benefícios, a faculdade de indicar

(106). - O documento, de difícil leitura, apresenta uma remessa de fundos dêsse banqueiro-mercador, por conta do auxílio ao rei pelo favor da naturalização, que chegou a 3.000 ducados (AGI. - Contadoria, 1391. Pagamento de Jorge Gramacho por carta de "naturaleza" por ser português).

(107). - AGI - Contratación 179. Carta de "Naturaleza de Duarte Fernandes da Costa.

(108). - Ibidem.

(109). - Idem, Contratación 179. Carta de "Naturaleza" de Simão Rodrigues Bueno.

(110). - "se le ofreció entre otras cosas que se le daria una naturalcza para las Indias por mi Consejo dellas para la persona que nombrase en la forma mas favorable que se huviese dado otra semejante naturaleza, libre de derechos y de qualquier otro gasto ..." (Ibidem). de Moraes.

(111). - Idem, Contratación 179. Carta de "Naturaleza" de Marcos Goes 
dois beneficiários de naturaleza (112). Em função dêste privilégio o comerciante-prestamista Francisco Lobo da Cunha adquiria, a 17 de agôsto de 1635, o direito de transacionar com as Índias Ocidentais de Espanha (113).

(Continua) .

(112). - Ibidem.

(113). - Idem, Contratación 179. Carta de "Naturaleza" de Francisco Lobo da Cunha. 